\title{
INTRASPECIFIC VARIATION IN Trichogramma bruni NAGARAJA, 1983 (HYMENOPTERA: TRICHOGRAMMATIDAE) ASSOCIATED WITH DIFFERENT HOSTS
}

\author{
QUERINO, R. B. and ZUCCHI, R. A. \\ Departamento de Entomologia, Fitopatologia e Zoologia Agrícola, Escola Superior de Agricultura "Luiz de \\ Queiroz”, Universidade de São Paulo, Avenida Pádua Dias, 11, CEP 13418-900, Piracicaba, SP, Brazil \\ Correspondence to: Ranyse Barbosa Querino da Silva, Departamento de Entomologia, Fitopatologia e Zoologia \\ Agrícola, Escola Superior de Agricultura “Luiz de Queiroz”, Universidade de São Paulo, Avenida Pádua Dias, 11, \\ CEP 13418-900, Piracicaba, SP, Brazil, e-mail: rbqsilva@ carpa.ciagri.usp.br \\ Received December 12, 2001 - Accepted February 18, 2002 - Distributed November 30, 2002
}

(With 9 figures)

\begin{abstract}
Trichogramma bruni is an insufficienty studied South American species whose limits are still not well defined. Thus, the objective of the present study was to characterize T. bruni taxonomically and to determine the association between morphological variations as well as host and habitat, based on morphological and biological studies. Specimens from the Escola Superior de Agricultura "Luiz de Queiroz" (ESALQ) collection, and from the University of California Riverside (UCR) and specimens collected from the vegetation of forest parks with native areas planted with eucalyptus in Piracicaba and Itatinga, State of São Paulo, were also analyzed. The holotype deposited at Univeridade Federal de Minas Gerais (UFMG) collection was also examined. The variability in the genital capsule of $T$. bruni observed both among individuals of the same progeny and among specimens from different hosts is remarkable and is mainly related to the dorsal lamina. Therefore, an association of diagnostic characters rather than the dorsal lamina alone should be used for the identification of T. bruni and intraspecific variations should be considered. The intraspecific variation observed for T. bruni is a factor that should be considered for its identification, since the influence of the environment (habitat + host) and the variation among individuals itself is responsible for the plasticity observed in the genital capsule. Heliconius erato phyllis, Hamadryas feronia, Erosina hyberniata and Mechanitis lysiminia are new hosts of $T$. bruni.
\end{abstract}

Key words: Trichogrammatidae, egg parasitoid, morphology, morfometric.

\section{RESUMO}

Variações intra-específicas em Trichogramma bruni Nagaraja, 1983 (Hymenoptera: Trichogrammatidae) associado a diferentes hospedeiros

Trichogramma bruni é uma espécie sul-americana pouco estudada e que ainda não tem seus limites bem definidos. Assim, o objetivo deste trabalho foi realizar uma caracterização taxonômica de T. bruni e analisar a associação das variações morfológicas com os hospedeiros e habitats, com base em estudos morfológicos e biológicos. Foram examinados espécimes da coleção da Escola Superior de Agricultura "Luiz de Queiroz" (ESALQ) e da coleção da University of California Riverside (UCR) e exemplares coletados na vegetação de hortos florestais com áreas nativas e plantadas com eucalipto em Piracicaba e Itatinga, Estado de São Paulo. O holótipo (Universidade Federal de Minas Gerais) foi examinado. A variabilidade na cápsula genital de T. bruni, tanto entre os indivíduos de uma mesma progênie como nos espécimes provenientes dos diferentes hospedeiros, é notória e relacionada principalmente à lâmina 
dorsal. Desta forma, para a identificação de T. bruni, uma associação de caracteres diagnósticos deve ser utilizada e as variações intra-específicas devem ser consideradas. A variação intra-específica apresentada por T. bruni deve ser considerada em seu reconhecimento, pois a influência do ambiente (habitat + hospedeiro) e a própria variação entre indivíduos são responsáveis pela plasticidade observada na cápsula genital. Heliconius erato phyllis, Hamadryas feronia, Erosina hyberniata e Mechanitis lysiminia são novos registros de hospedeiros.

Palavras-chave: Trichogrammatidae, parasitóide de ovos, morfologia, morfometria.

\section{INTRODUCTION}

Several Trichogramma species do not show a clear morphological characterization, a fact that might cause problems in identification, which is mainly based on morphological characteristics, especially the male genitalia (Nagarkatti \& Nagaraja, 1971). This is the case of T. bruni, an insufficienty studied South American species whose limits are still not well defined. Therefore, many specimens from Central and South America have been called "nr. bruni" (Pinto, 1998).

T. bruni was originally described from specimens collected in Minas Gerais, Brazil, from eggs of an unidentified Notodontidae species (Nagaraja, 1983). The distribution and hosts of this species have been described by Zucchi \& Monteiro (1997) and Pinto (1998). Information about its hosts and habitats, however, is scarce, probably due to the fact that the species is mainly found in forest environments. Consequently, the association between morphological variations its habitat and hosts, has not been studied yet, because only few specimens have been collected.

The morphological variations observed for T. bruni have cast doubt on the identification of this species, taking into account that these variations might be the result of environmental influences or of the presence of incipient and/or cryptic species in the Neotropical region. Therefore, the objective of the present study was to characterize $T$. bruni taxonomically and to determine the association between morphological variations and host and habitat, based on morphological and biological studies.

\section{MATERIAL AND METHODS}

\section{Study material}

Specimens from Brazil deposited at Escola Superior de Agricultura "Luiz de Queiroz" (ESALQ) collection as well as from Argentina,
Costa Rica, Trinidad \& Tobago and Venezuela, called "nr. T. bruni", housed at University of California (Riverside, TX, USA) (UCR) collection, were studied. The holotype deposited at Universidade Federal de Minas Gerais (UFMG) collection was also examined. Specimens collected from the vegetation of forest parks with native areas planted with eucalyptus in Piracicaba and Itatinga, State of São Paulo, were also analyzed. The eggs of the host insects were individualized in the laboratory and incubated in glass tubes until hatching of the parasitoids, which were then mounted on microscopic slides, using Hoyer's.

Voucher specimens were deposited at the ESALQ/USP (Entomology) collection.

\section{Morphological characterization}

The characterization of $T$. bruni was based on morphology and morphometric data obtained for the male structures. The measurement was obtained using an ocular micrometric attached to a microscope (length and distance in millimeter). The terminology and anatomical terms are based on Pinto (1998).

Quantitative data, reported as mean and standard deviation, were obtained for 25 specimens collected from eggs of Heliconius erato phyllis (Fabr., 1775) (Lepidoptera: Nymphalidae), on Passiflora sp., Piracicaba, SP, Brazil.

For characterization, illustrations of the male genital capsule and antennae and hind wings were produced using a light camera (magnification 16x) and video camera connected to a microscope (400 and 1000x). These structures were also studied by scanning electron microscopy (Zeiss DSM 940A and LEO $435 \mathrm{VP}$ ) with $5-20 \mathrm{kV}$ acceleration and the generated images were digitized.

\section{Morphological variations}

For the definition of morphological characteristics, variations in T. bruni specimens obtained from different hosts and habitats as well as 
morphological variations between individuals were analyzed in order to determine variability and to correlate it with ecological variables. The main morphological variations were photomicrographed. Individual variation was also determined in specimens obtained from a single population and those obtained from isofemales, were obtained by individualizing a recently hatched $T$. bruni couple in each assay tube for $24 \mathrm{~h}$. After this period, Anagasta kuehniella (Zeller) (Lepidoptera: Pyralidae) eggs previously sterilized with ultraviolet light were placed in the tubes for parasitization. The isofemale line showing the highest parasitism was selected and then multiplied in the laboratory until the fifth generation.

\section{Multivariate morphometric analyses}

Variations in morphological characters observed for $T$. bruni collected from different hosts and habitats were determined by principal component analysis. Canonical variate analysis was also performed to determine the discrimination pattern and to identify the two canonical variables that best define $T$. bruni, as well as to compare the results obtained by principal component analysis.

For these analyses, T. bruni specimens obtained from: 1 . isofemale lines derived from populations collected from Heliconius erato phyllis (Fabr., 1775) eggs in Piracicaba, SP $(\mathrm{n}=25) ; 2$. an unknown host in Itatinga, SP $(\mathrm{n}=14) ; 3$. Erosina hyberniata Guenée, 1857 eggs in Piracicaba $(\mathrm{n}=10)$; and 4. Mechanitis lysimnia (Fabr., 1793) eggs in Piracicaba $(n=7)$ were used. Also, T. lasallei $(\mathrm{n}=30)$ and $T$. rojasi $(\mathrm{n}=12)$, two species closely related to $T$. bruni, collected from Anticarsia gemmatalis Hübner, 1818 eggs on soybean in Curitiba, PR, were studied.

The following morphometric characters were analyzed: length of the flagellum (FL), largest width of the flagellum (WF), length of the largest seta of the flagellum (LSF), length of the largest seta of the fringe of the forewing (LSFFW), length of the edeagus (LE), length of the apodemas (LA), length of the ventral ridge (LVR), length of the genital capsule (LGC), width of the genital capsule (WGC), basal distance (BD), apical distance (AD), apical width (AW), length of the dorsal opening (LDO), width of the dorsal lamina (WDL), length of the dorsal lamina (LDL), length of the posterior extension of the dorsal lamina (LPEDL), distance from the ventral processes to the basis of the intervolsellar process (DVP), length of the posterior tibia (LPT), length of the scape of the antenna (LSA). The data were log transformed to homogenize variances and analyses were carried out using the SAS program (1990).

\section{Crossings}

Reproductive compatibility studies were carried out between T. bruni and T. lasallei. Bidirectional crossings (homogamic and heterogamic) and the mode of reproduction were studied using the methodology described by Pinto et al. (1991). All crossings were concomitantly carried out in an acclimatized chamber at a temperature of $25 \pm 0.5^{\circ} \mathrm{C}$ and relative humidity of $80 \pm 10 \%$ on a 14-h photoperiod. Progeny production was determined by counting males and females. Fertility of the females was also assessed. To determine whether thelytokous females also occur at other temperatures, female virgins were reared at 18,25 and $30^{\circ} \mathrm{C}$.

\section{RESULTS}

\section{New hosts and geographic distribution}

T. bruni is only found in the Neotropical region, with distribution in Brazil, Bolivia, Costa Rica, Mexico, Trinidad \& Tobago and Venezuela. The host species recorded in this region thus far only include members of the Notodontidae and Noctuidae families. Therefore, Heliconius erato phyllis, Hamadryas feronia L., 1758 Erosina hyberniata and Mechanitis lysimnia are new hosts of $T$. bruni (Table 1).

\section{Morphological characterization}

Trichogramma bruni Nagaraja, 1983: 38 (Figs. 1-2); Sorokina, 1993: 35; Zucchi \& Monteiro, 1997: 53; Pinto, 1998: 79 and 81 (as "nr. T. bruni").

Antennae: long flagellum $(0.16 \pm 0.02)$; ratio between the length and width of the flagellum, $6.17 \pm 0.60$; long setae of the flagellum $(0.09 \pm$ $0.01)$, tapered with a pointed apex; length of the largest seta of the flagellum/largest width of the flagellum ( $3.49 \pm 0.18)$; length of the flagellum/ length of the posterior tibia $(1.24 \pm 0.08)$; oval sensilla basiconica, formula 2(1)-2(1)-2-0(1)-1; 
sensilla placoidea $0.01 \pm 0.00 \mathrm{~mm}$ above the apex of the flagellum.

Forewings: ratio between the width and length of the wing $(0.52 \pm 0.04)$; length of the largest seta of the fringe of the wing/length of the posterior tibia $(0.23 \pm 0.05)$; length of the largest seta of the fringe of the forewing/width of the forewing $(0.13 \pm 0.03)$. The density of the setae between the 4 th and 5 th track was $8.39 \pm 2.91$ (4-18).

Hind wings: the number of setae in the anterior and posterior track ranged from 0 to 1 and 1 to 6 , respectively. The anterior track did not exceed half the median track.

Scutellum: the ratio between the anterior and posterior seta pair was $0.18 \pm 0.05$, with the setae of the anterior pair being very small $(0.01 \mathrm{~mm})$ and difficult to visualize.

Genitalia male: a longer $(0.11 \pm 0.01)$ than wider $(0.04 \pm 0.0)$ genital capsule, ratio between the width and length of the genital capsule $(0.38 \pm$ 0.02); ratio between the apical distance and length of the genital capsule $(0.23 \pm 0.02)$; apical width/ width of the genital capsule $(0.72 \pm 0.04)$; length of the dorsal lamina/length of the genital capsule $(0.37 \pm 0.05)$; absent dorsal ridge; length/width of the dorsal lamina $(1.21 \pm 0.20)$; the posterior extension of the dorsal lamina generally showed a pointed apex, length of the posterior extension of the dorsal lamina $(0.03 \pm 0.00)$; ratio between the length of the dorsal opening and the length of the dorsal lamina $(1.65 \pm 0.20)$; length of the posterior extension of the dorsal lamina/length of the dorsal lamina $(0.76 \pm 0.12)$; long ventral ridge $(0.06 \pm 0.00)$, measuring half the genital capsule; ridge/basal distance $(0.63 \pm 0.05)$; basal distance/ length of the genital capsule $(0.79 \pm 0.05)$; ventral processes relatively close to the basis of the intervolsellar process $(0.01 \pm 0.002)$; length of the edeagus/length of the posterior tibia $(0.44 \pm 0.03)$; apodemas/edeagus $(0.88 \pm 0.07)$.

\section{Material examined}

BRASIL. MINAS GERAIS: Belo Horizonte, holotype, 24-ii-1978, eggs of Notodontidae, G. W. G. de Moraes, P. Brun \& L. A. Soares col. (UFMG). SÃO PAULO: Piracicaba, v-1999, Heliconius erato phyllis eggs on Passiflora sp., 25 males. J. A. Cerignoni col. (ESALQ); Piracicaba, 2-vii-1999, Erosina hyberniata eggs on Acnistus arborescens, 10 males, R. B. Querino col. (ESALQ); Piracicaba, Tupi forest park, 20-ix-1999, Mechanitis lysimnia eggs on "Juá bravo", 24 males, R. B. Querino col. (ESALQ); Itatinga, 6-X-1999, host unknown, on an eucalyptus sub-forest, 24 males, R. B. Querino col. (ESALQ); Piracicaba, 16-vi2000, Hamadryas feronia eggs on Dalechampia sp., 4 males, J. A. Cerignoni col. (ESALQ); ARGENTINA. MISSIONS: Porto Iguazu, 27-xii-1990/ 06-i-1991, roadside forest, 2 males, S. \& J. Peck col. (U.C.R.); COSTA RICA. HEREDIA, Porto Viejo, i, iii e iv-1994, La selva, 100 m, 1 male, (U.C.R.); TRINIDAD \& TOBAGO. St. GEORGE, Gasparillo, 5 and 15-xi-1987, M. T. Grass/Forest edge, 1 male (U.C.R.); VENEZUELA. LARA: Sanare, 12-vii-1983, tropical plant, host unknown, E. R. Oatman col., 2 males (U.C.R.); Aragua, Henri Pittier National Park, La Trilla, 200 m SS, L. Masner col. (U.C.R.).

TABLE 1

Records of new hosts and geographic distribution of Trichogramma bruni in the State of São Paulo, Brazil.

\begin{tabular}{|l|c|c|c|}
\hline Insect host & Associated plant & Collector & Site \\
\hline Hamadryas feronia (Nymphalidae) & Eucalyptus sub-forest & R. B. Querino & Itatinga (forest park) \\
\hline Erosina hyrbeniata (Geometridae) & Acnistus arborescens & R. B. Querino & Piracicaba (ESALQ) \\
\hline Mechanitis lysimnia (Nymphalidae) & "Juá bravo" & R. B. Querino & Piracicaba (Tupi forest park) \\
\hline $\begin{array}{l}\text { Heliconius erato phyllis } \\
\text { (Nymphalidae) }\end{array}$ & Passiflora sp. & J. A. Cerignoni & Piracicaba (netting/ESALQ) \\
\hline
\end{tabular}




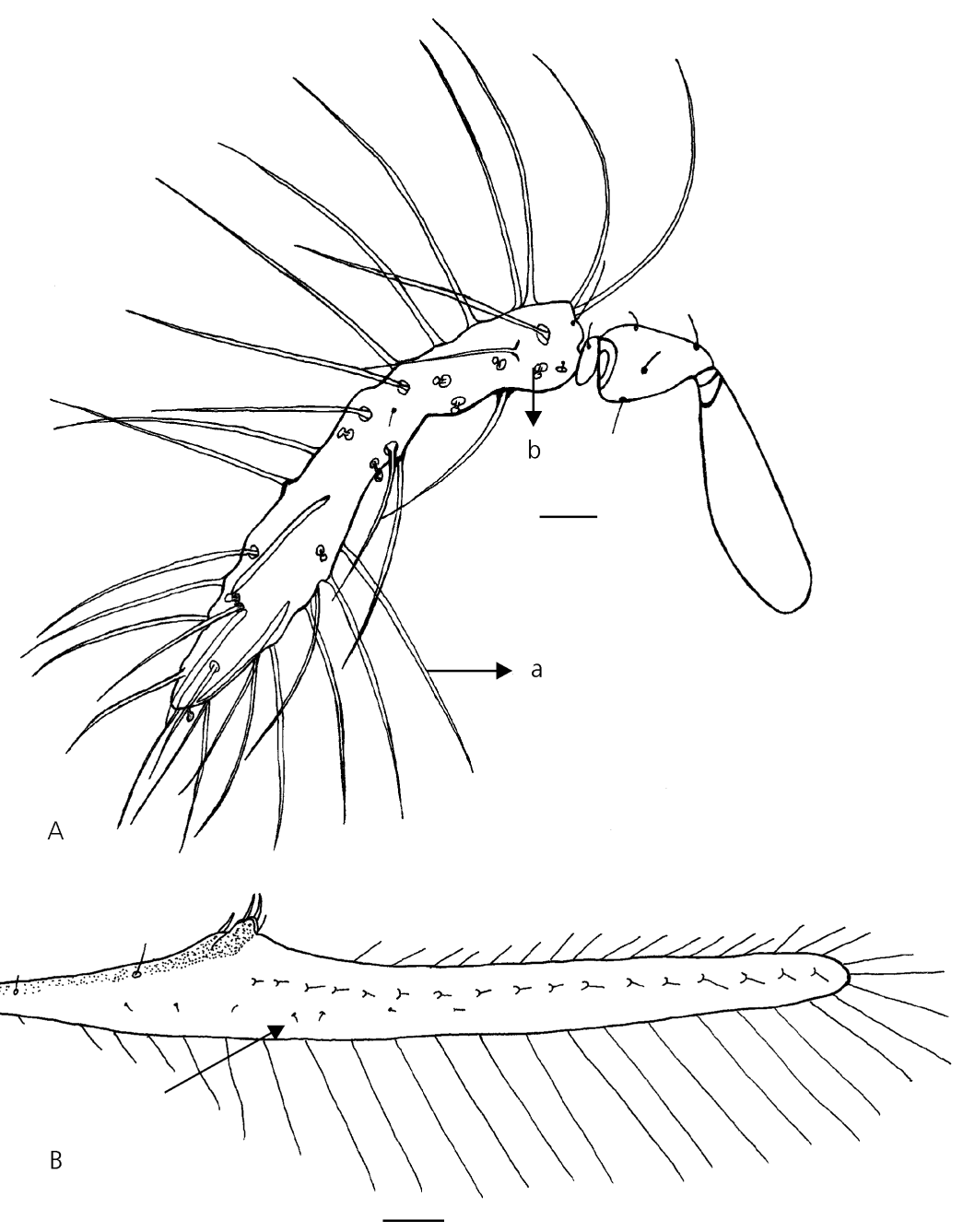

Fig. 1 - A. Trichogramma bruni antenna: a - flagelliform setae; b - sensilla basiconica; B. Hind wing of Trichogramma bruni: posterior row of setae (scale: $0.02 \mathrm{~mm}$ ).

\section{Morphological variations}

Individual variation in the genital capsule was clearly observed on specimens originating at isofemale lines (Fig. 3). The dorsal lamina varied in the width of its posterior extension, with individuals showing a wider basis. The apex of the dorsal lamina ranged in shape from round to pointed. The ventral processes varied regarding their position, and were found slightly more distant from the basis of the intervolsellar process. Sensilla basiconica were present on the antenna at position 4 . The same morphological variations were noted for T. bruni specimens collected from $H$. erato phyllis eggs and those collected in Itatinga (Fig. 4).
The variations observed among individuals of a single host were similar to those observed from different hosts. However, T. bruni collected from $M$. lysimnia eggs showed an extended genital capsule with a shorter, wider and darker dorsal lamina (Figs. 5c-d). Similar characteristics were observed for a specimen collected at Missions in Argentina, which was called "nr. T. bruni" by Pinto (1998). In contrast, samples obtained from Costa Rica, Trinidad \& Tobago (St. George) and Venezuela, which were also called "nr. T. bruni" by Pinto (1998), were morphologically similar to the other specimens collected in Brazil. 

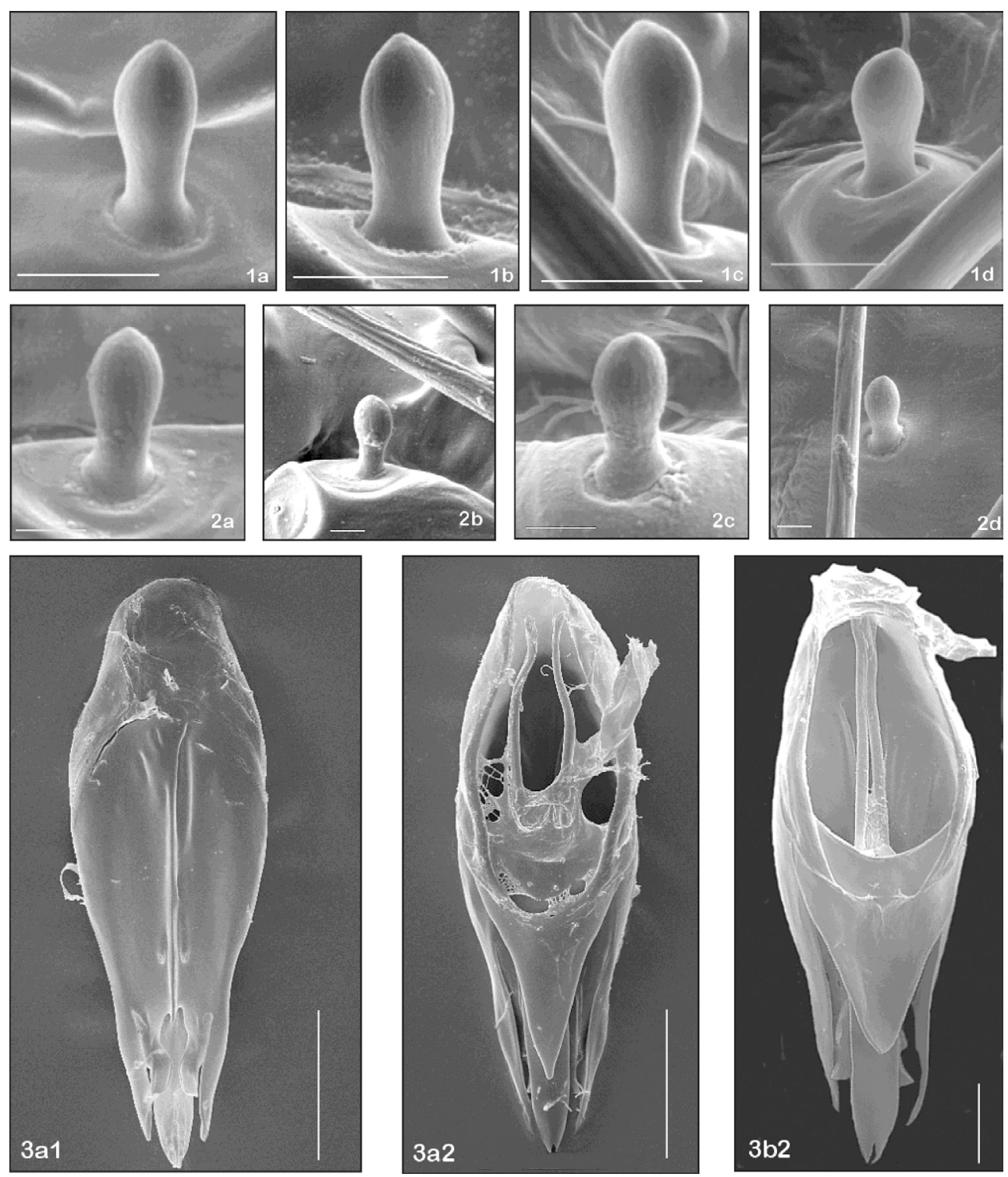

Fig. 2 - 1. Sensilla basiconica of Trichogramma bruni collected from Heliconius erato phyllis eggs: a - position 1 (16790x, $1 \mu \mathrm{m}) ; \mathrm{b}$ - position $2(22300 \mathrm{x}, 1 \mu \mathrm{m}) ; \mathrm{c}$ - position $3(23330,1 \mu \mathrm{m}) ; \mathrm{d}$ - position $4(15990 \mathrm{x}, 1 \mu \mathrm{m}) ; 2$. Sensilla basiconica of Trichogramma bruni collected in Itatinga, SP: a - position $1(10000 \mathrm{x}, 1 \mu \mathrm{m})$; b - position $2(5000 \mathrm{x}, 1 \mu \mathrm{m})$; c - position $3(1000 \mathrm{x}, 1 \mu \mathrm{m}) ; \mathrm{d}$ - position $4(5000 \mathrm{x}, 1 \mu \mathrm{m})$. 3. Genital capsule of Trichogramma bruni: 1 - collected from Heliconius phyllis eggs in Piracicaba, SP: a - ventral view (1610x, $10 \mu \mathrm{m}), \mathrm{b}$ - dorsal view (1620x, $10 \mu \mathrm{m}), 2$ - collected in Itatinga, SP: $\mathrm{b}$ - dorsal view $(857 \mathrm{x}, 10 \mu \mathrm{m})$.

The color of the T. bruni specimens varies according to host and habitat, with specimens from Venezuela showing a light (state of Aragua) and dark color (state of Lara, Sanare). In Brazil, specimens from M. lysimnia eggs presented a dark or light color, with morphological differences in the genital capsule (Fig. 5), while specimens obtained from the other hosts were light yellow. Nagaraja (1983) described T. bruni as "yellow with fuscous mesoscutum and anteriormost abdominal terga", but he did not make clear if this observation was made on living material or on specimens mounted on slides. Pinto (1998) reported that color may vary from light brown to dark. 

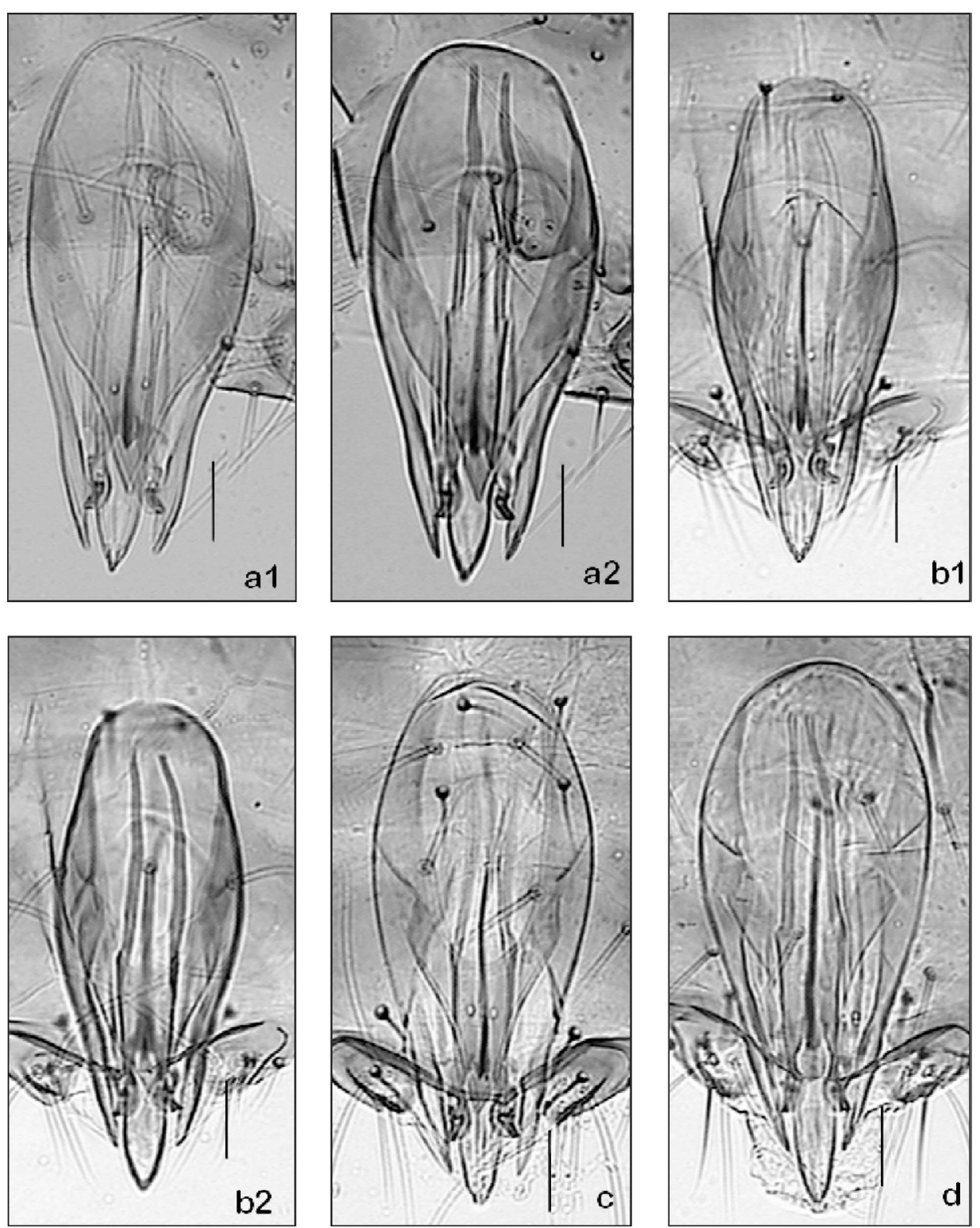

Fig. 3 - Variation in the genital capsule among T. bruni individuals from Isofemale line: 1 - ventral view e 2 - dorsal view (scale: $10 \mu \mathrm{m}$ ).

\section{Multivariate analysis}

Principal component analysis showed that T. bruni obtained from different hosts and habitats form a cluster (Fig. 6). The first principal component accounted for about $52 \%$ of total variation, the second for $22 \%$ and the third for $9 \%$. The first two components corresponded to $77 \%$ of the total variance present in the matrix of covariance. The autovector coefficients showed positive and negative values for all morphometric variables analyzed, indicating a contrast between variables and providing information about differences in body shape among populations. In the first component, the variable distance from the ventral processes to the basis of the intervolsellar process (DVP) was the most important, since the autovector showed the highest absolute value (0.954). 

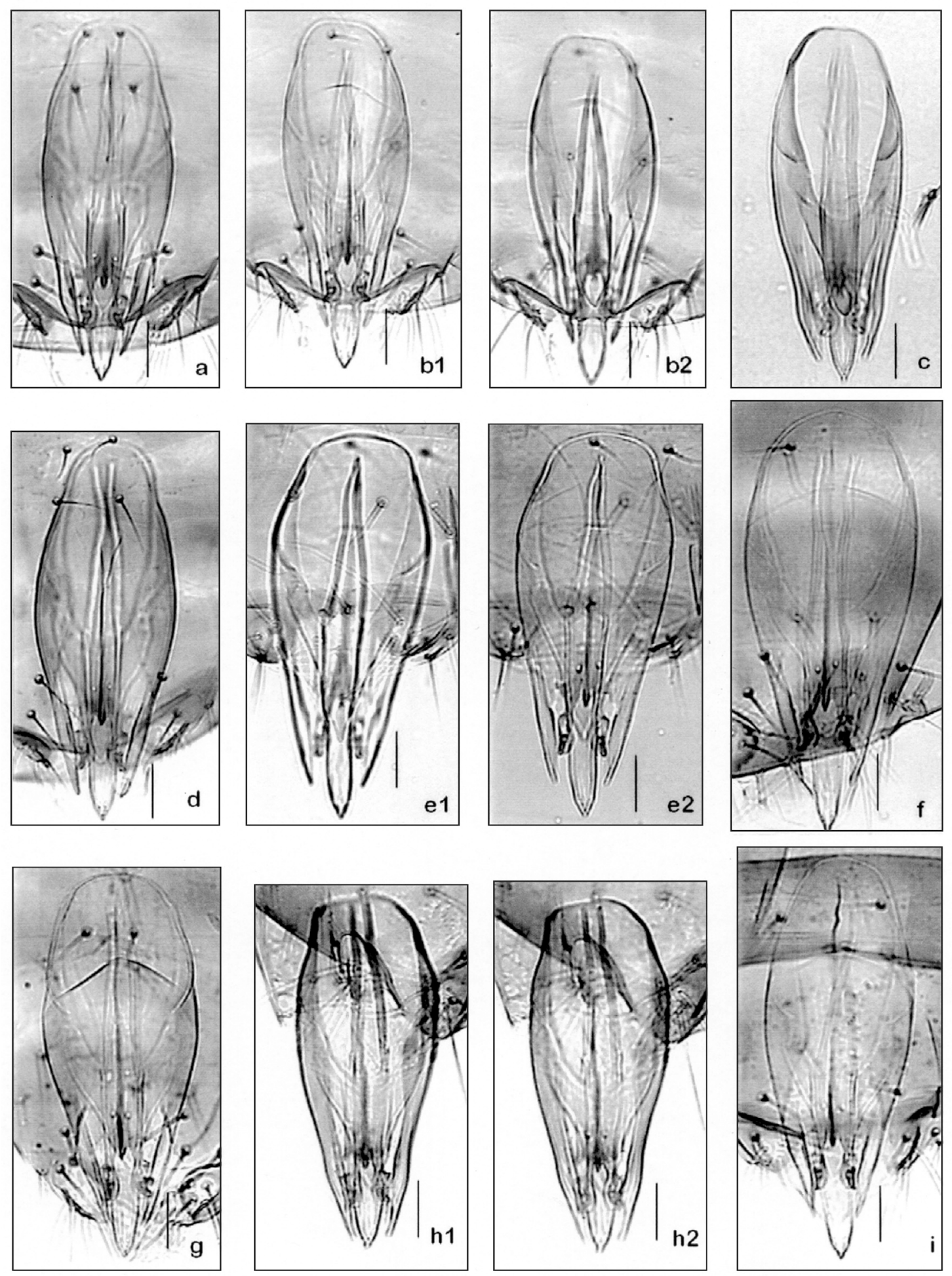

Fig. 4 - Variation in the genital capsule of T. bruni: Itatinga-SP (a-c); eggs of Heliconius erato phyllis in Piracicaba-SP (d-i). 1 - ventral view e 2 - dorsal view (scale: $10 \mu \mathrm{m}$ ). 

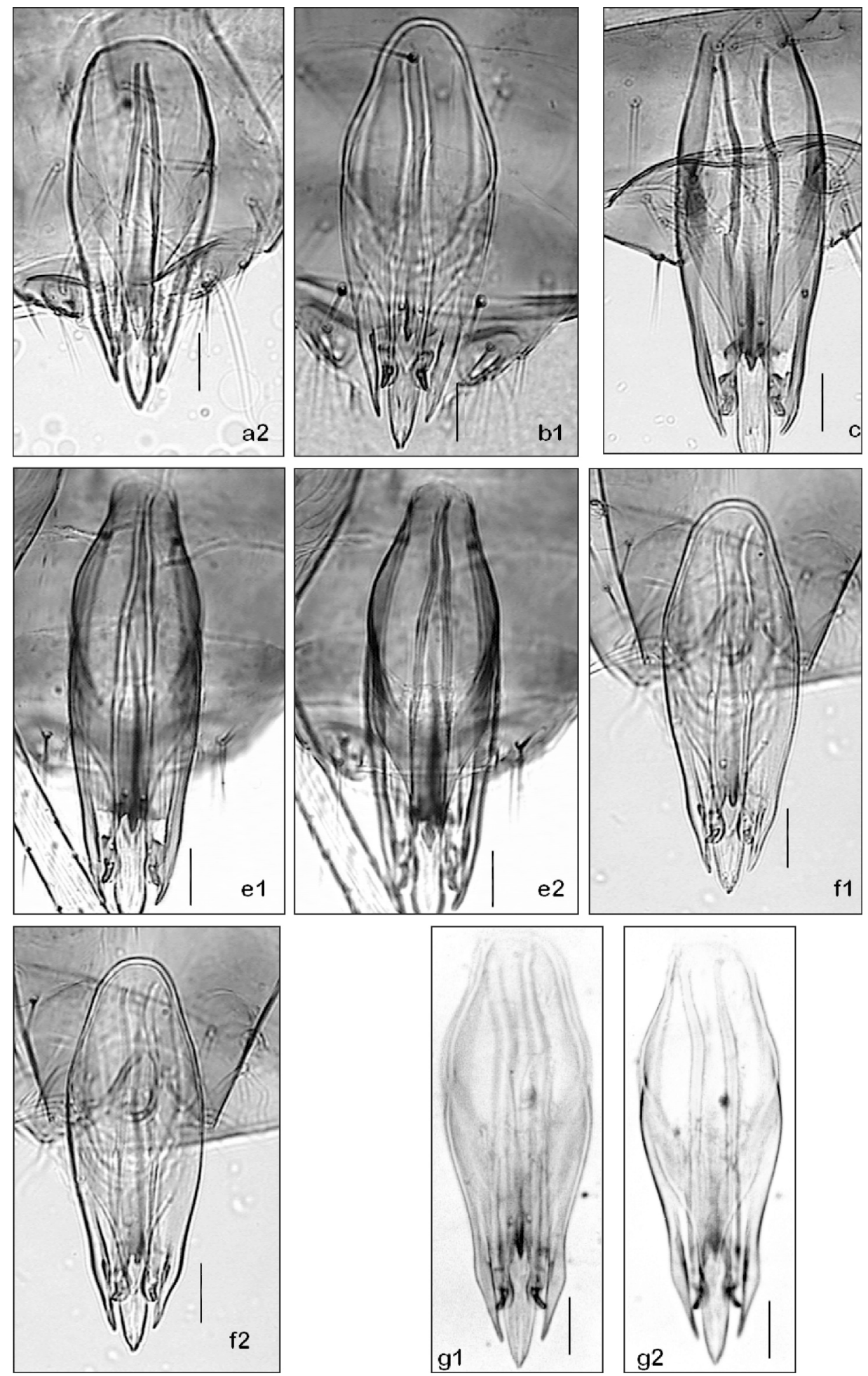

Fig. 5 - Variation in the genital capsule of T. bruni collected from eggs of Erosina Hyberniata (a), Hamadryas feronia (b), Mechanitis lysimnia $(\mathrm{c}-\mathrm{d}=$ dark specimen, $\mathrm{e}=$ clear specimens) and (f) genital capsule of the holotype. 1 - ventral view e 2 - dorsal view (scale: $10 \mu \mathrm{m}$ ). 


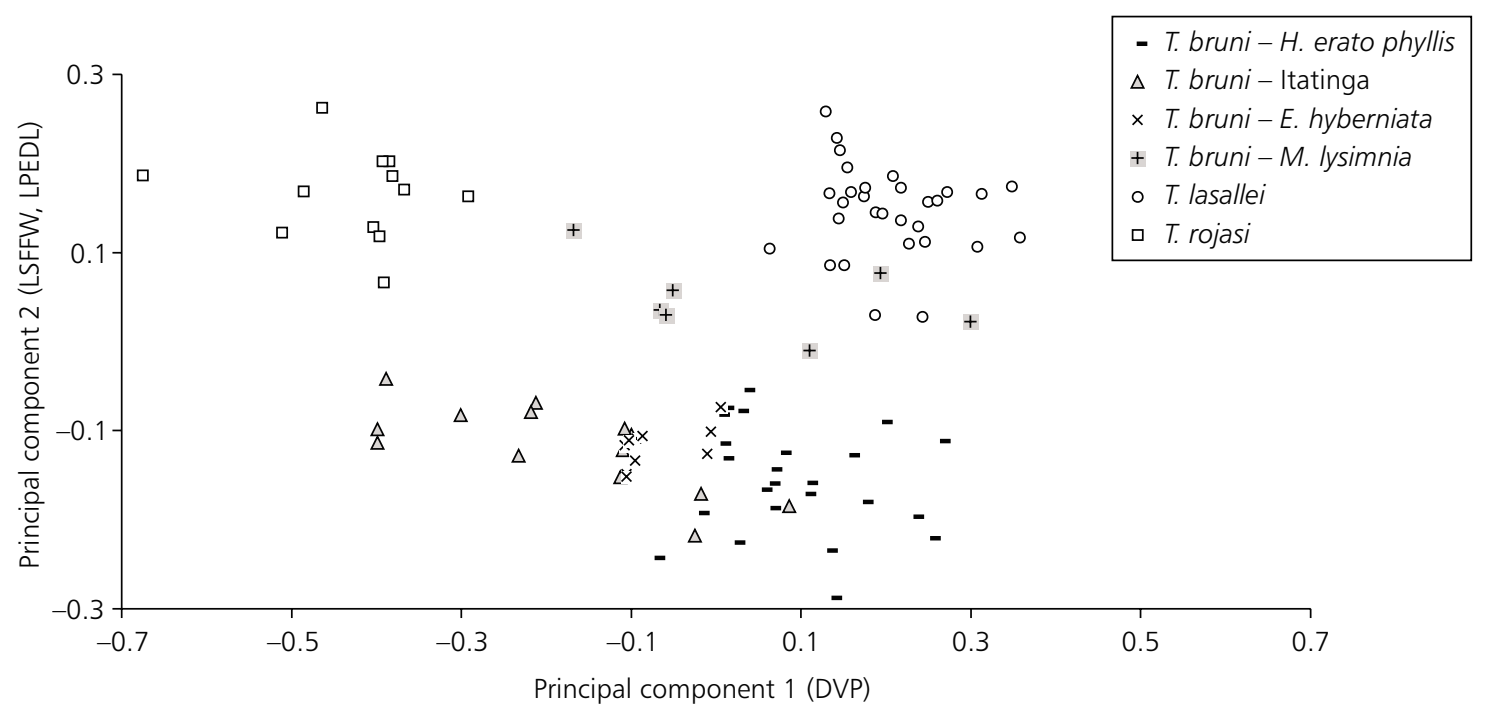

Fig. 6 - Ordination of T. bruni, T. lasallei and T. rojasi within the first two components.

In the first component axis represented mainly by DVP, no clear separation could be made between T. bruni and T. lasallei, but a clear difference was noted between $T$. lasalle $i$ and $T$. rojasi. In contrast, the second component was more influenced by the variables length of the larger setae of the fringe of the forewing (LSFFW) and length of the posterior extension of the dorsal lamina (LPEDL), with the autovectors showing values of 0.596 and 0.400 , respectively. In the axis of this component, no difference was observed between T. bruni specimens obtained from different hosts, except for those collected from M. lysimnia, which occupied an intermediate situation between T. bruni and T. lasallei. In addition, the LSFFW and LPEDL variables, which represent the second variable, clearly separated $T$. bruni from $T$. lasallei and $T$. rojasi, although they did not distinguish between T. lasallei and T. rojasi.

Canonical variate analysis (Fig. 7) showed an order similar to that obtained by principal component analysis. Univariate statistics ( $F$ test) and the multivariate Wilks' Lambda ( $<<0.0001)$, Pillai's Trace $(p<0.0001)$, Hotelling-Lawley Trace $(\mathrm{p}<0.0001)$ and Roy's Greatest Root tests $(\mathrm{p}<$ 0.0001 ) revealed significance for all variables. The first two canonical axes were extracted from a matrix resulting from the product of the covariance matrix between groups and the covariance matrix within groups. The first canonical variable accounted for $56 \%$ of total variance and the second for $31 \%$. The first two canonical axes corresponded to $87 \%$ of variation. In the first canonical axis, the most important variables were LSFFW, LPEDL and CSF, with absolute values of $0.880,0.726$ and 0.725 , respectively. DVP and LVR, with absolute values of 0.888 and 0.703 , respectively, were the most important variables in the second canonical axis.

Canonical variate analysis showed that $T$. bruni from different hosts form a cluster. However, specimens obtained from M. lysimnia occupied an intermediate situation due to the morphological variables obtained for the genital capsule, especially when analyzing the first canonical axis (represented by LSFAA, LPEDL and LSF), whereas the second axis (represented by DVP and LVC) did not distinguish between the other specimens and T. bruni. A clear separation was observed between the species studied, with $T$. lasallei being closer to T. bruni with respect to both the first and second canonical variables. The proximity of these two species has also been observed by Pinto (1998) upon phylogenetic analysis. However, T. rojasi remains isolated and distant from T. bruni.

\section{Diagnosis}

Based on the intraspecific variations, the characters that best identified $T$. bruni are: antennae 
with long flagelliform setae and oval sensilla basiconica; genitalia with a long genital capsule; a typical dorsal lamina with a wide basis and a posterior extension stretching to a pointed apex; a clearly visible and long ventral ridge, occupying about $2 / 3$ of the length of the genital capsule; ventral processes located anteriorly and separated by the basis of an intervolsellar process, and a short intervolsellar process. However, some specimens differ from holotype (Fig. 5f), i.e., a longer genital capsule, a dorsal lamina varying in the width of the basis and a shorter posterior extension compared to normal. Color should not be used to identify $T$. bruni.

Among the Trichogramma species found in the Neotropical region, T. lasallei and T. rojasi are more closely related to $T$. bruni, in addition to other species discussed by Pinto (1998). Sensilla basiconica are frequently observed at position 4 in T. bruni, but not in T. lasallei or T. rojasi. These two species show larger and darker anterior setae of the scutellum, while in T. bruni these structures are reduced and difficult to visualize. The density of setae on the forewings is about two times lower in T. bruni and T. lasallei (8.39 and 8.40, respectively) compared to $T$. rojasi (16.92). On the hind wings of T. bruni and T. lasallei, the setae of the posterior track do not reach half the median track, while in T. rojasi they reach the apex of the wing. In contrast to T. bruni, the genital capsule of T. lasallei and T. rojasi is sclerotized and dark. The ventral ridge is typically extended in $T$. bruni and shorter in T. rojasi, while in T. lasallei the anterior limit is not visible. Another characteristic differentiating $T$. rojasi is the presence of ventral processes very close to the basis of the intervolsellar process (which are distant in T. bruni and T. lasallei). The ratio between the length and width of the dorsal lamina, with means of $1.21 \pm$ 0.20 (T. bruni), $1.38 \pm 0.09$ (T. lasallei) and $1.46 \pm$ 0.13 (T. rojasi) indicates a wider basis of the dorsal lamina for $T$. bruni. In general, the structures of T. rojasi are larger than those of the other two species.

\section{Crossings}

The crossings performed between T. bruni and T. lasallei helped in the separation and confirmation of the species, especially in the case of T. bruni since doubts remained regarding the identification of this species due to the remarkable intraspecific variations. A bidirectional crossing between T. lasallei and $T$. bruni demonstrated that the species are incompatible (Table 2), since only males were produced, i.e., females of the two species were not fertilized during the heterogamic crossings (Fig. 8).

TABLE 2

Mean number of male and female descendants and total number of parasitized eggs obtained upon crossing of T. lasallei $(\mathrm{L})$ and T. bruni $(\mathrm{B})$ at $25^{\circ} \mathrm{C}$.

\begin{tabular}{|l|c|c|c|c|c|c|}
\hline Crossings & $\mathbf{n}$ & N. of males & N. of females & Total & Parasitized eggs \\
\hline Heterogamic & 18 & $30.17 \pm 8.40$ & 0 & $30.17 \pm 8.40$ & $31.05 \pm 8.99$ \\
\hline 1. L male x B female & 16 & $17.87 \pm 9.44$ & 0 & $17.87 \pm 9.44$ & $18.50 \pm 10.22$ \\
\hline 2. B male x L female & 9 & $14.22 \pm 4.38$ & $11.33 \pm 6.18$ & $25.55 \pm 7.52$ & $27.55 \pm 7.21$ \\
\hline Homogamic & 10 & $15.50 \pm 7.11$ & $12.10 \pm 5.72$ & $27.60 \pm 9.14$ & $31.60 \pm 9.87$ \\
\hline 3. L male x L female & 10 & 23.9 & 0 & 23.9 & \\
\hline 4. B male x B female & 11 & 35.5 & 0 & 35.5 & 36.73 \\
\hline Mode of reproduction & & & & \\
\hline L female virgin
\end{tabular}




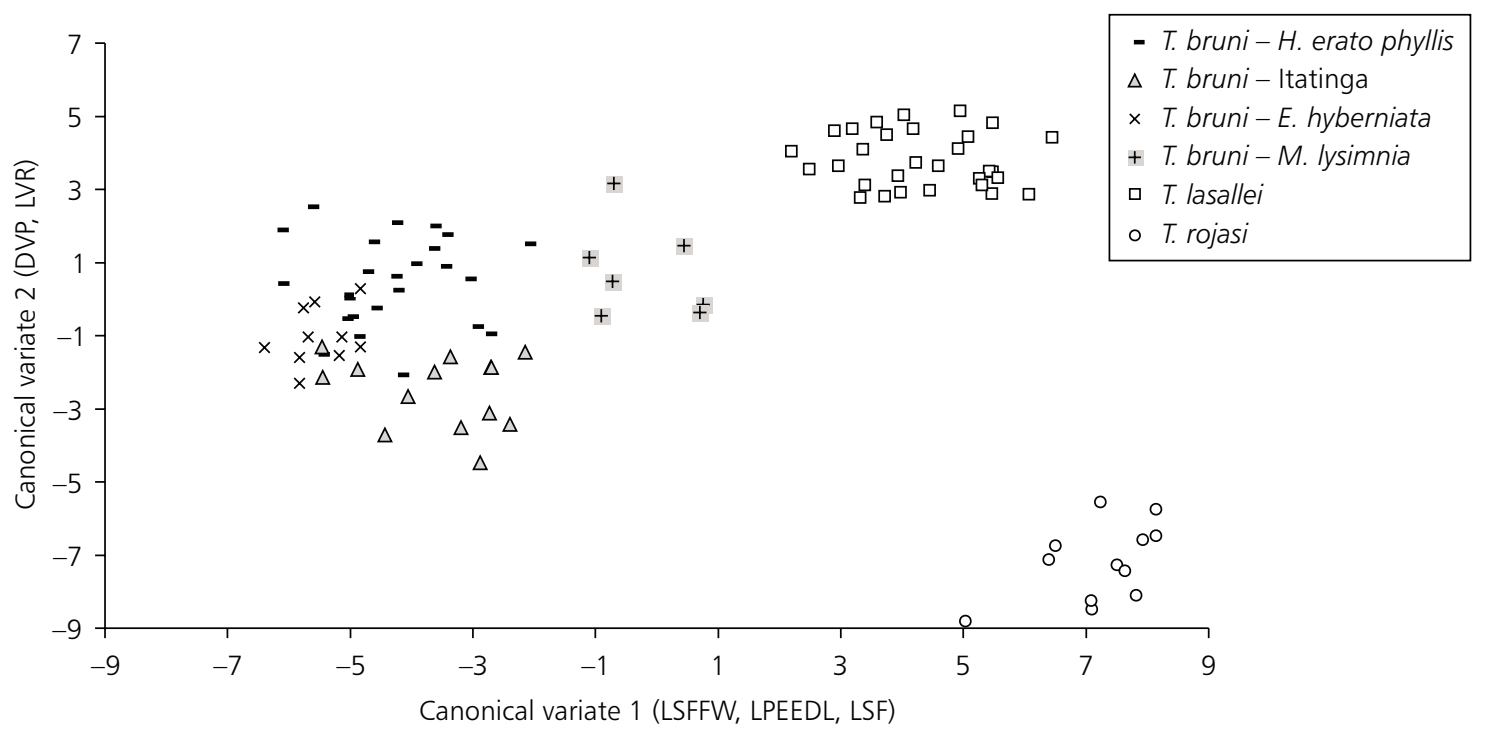

Fig. 7 - Ordination of T. bruni, T. lasallei and T. rojasi within the first and second canonical axis.

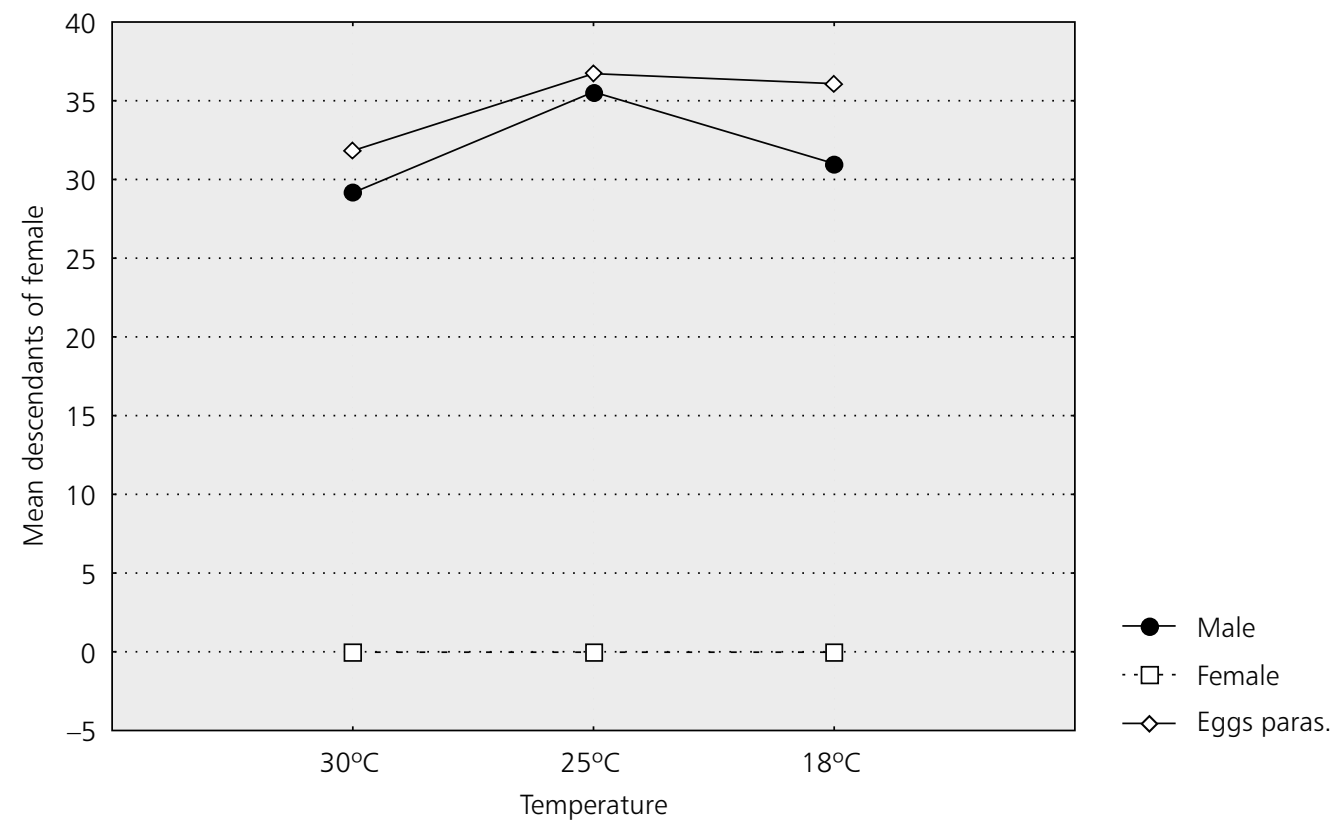

Fig. 8 - Descendants of female T. bruni virgins at different temperatures. 
With respect to the mode of reproduction at $25^{\circ} \mathrm{C}$, female virgins only produced males, thus indicating that the two species are arrhenotokous. The descendants of each species were found to be fertile. Crossings with $T$. rojasi were not possible, since this species has not been reared in the laboratory.
A larger number of female descendants was observed for some T. bruni samples. Thus, we determined whether thelytokous females can occurr at other temperatures. However, female T. bruni virgins reared at 18,25 and $30^{\circ} \mathrm{C}$ only produced males (Fig. 8), indicating that temperature did not influence the mode of reproduction of this species.
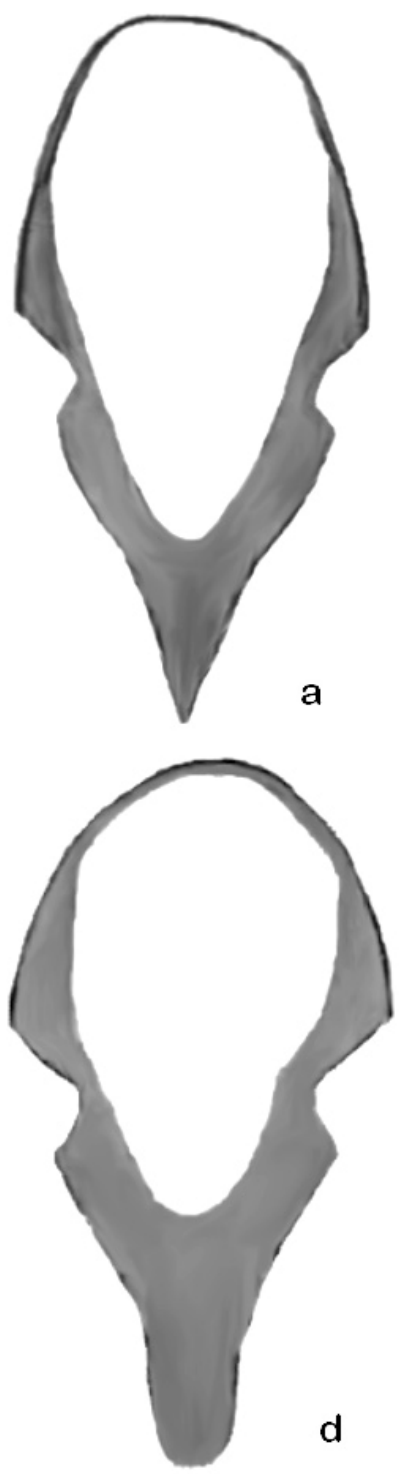

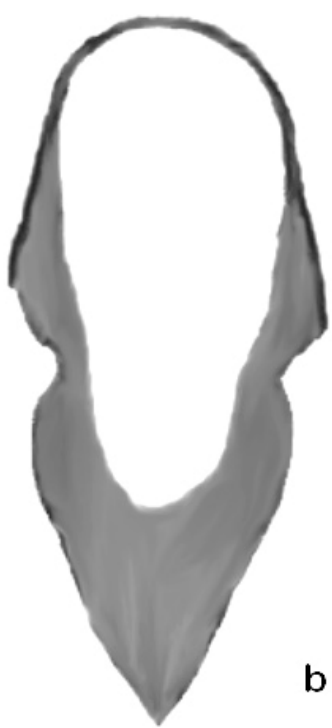

$b$

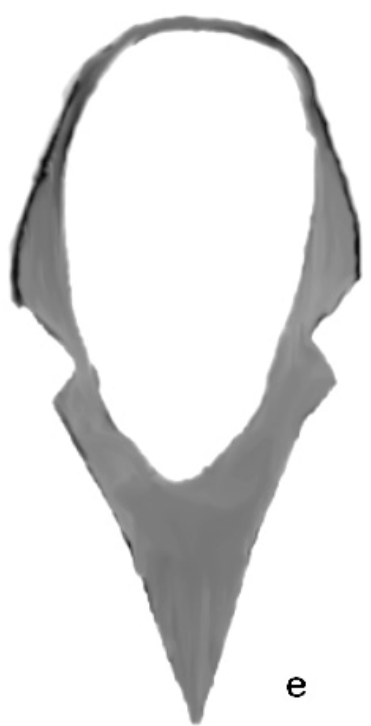

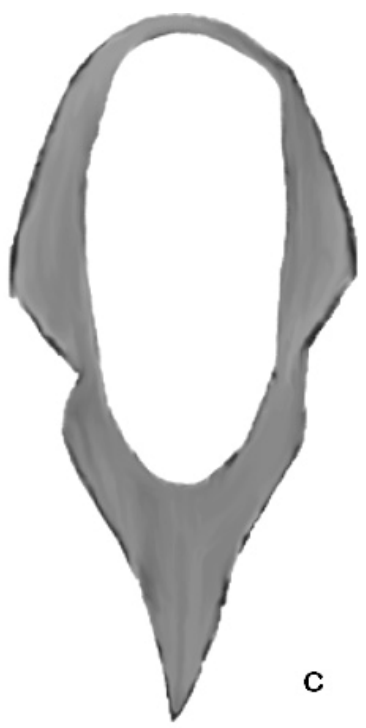

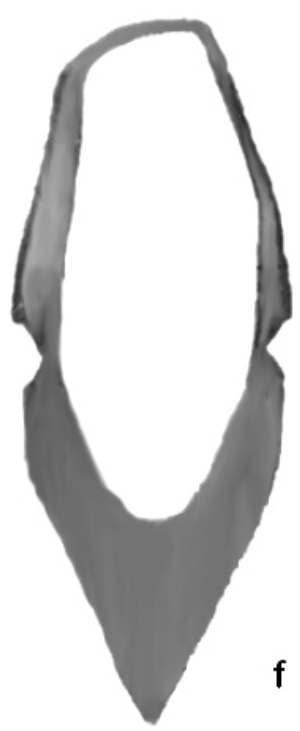

Fig. 9 - Sketches of the variations of the dorsal lamina of Trichogramma bruni: specimens from isofemale line (a-d); from Heliconius erato Phyllis (e) and Mechanitis lysimnia (f). 


\section{DISCUSSION}

The new T. bruni records were obtained from eggs of lepidopterous species not economically important, collected in a sub-forest and in the margin vegetation of forest areas. Specimens collected from Erosina hyberniata eggs were found in the margin vegetation of a forest reserve area and those collected from Heliconius erato phyllis and Hamadryas feronia were found in a butterfly rearing unit covered with netting. The fact that only T. pretiosum and T. atopovirilia, but not T. bru$n i$, were collected during surveys carried out in Piracicaba on economically important lepidopterous pests, such as Spodoptera frugiperda (J. E. Smith, 1797) and Helicoverpa zea (Boddie, 1850), clearly indicates a specificity of $T$. bruni regarding habitat and wild hosts. For example, in a survey carried out in a forest park during a period of one year, T. bruni was the most abundant and most frequent species collected with a suction trap (Querino \& Zucchi, 2000).

The variability in the genital capsule of $T$. bruni observed both among individuals of the same progeny and among specimens from different hosts is well known and is mainly related to the dorsal lamina (Fig. 9), reinforcing the plasticity of this character, as also observed by Pinto et al. (1989). Therefore, an association of diagnostic characters rather than the dorsal lamina alone should be used for the identification of T. bruni and intraspecific variations should be considered.

In this way, the two multivariate analyses carried out here showed that the differences observed for T. bruni are influenced by the host and habitat. Specimens collected from M. lysimnia eggs showed a greater morphological differentiation than those obtained from the other hosts, indicating genetic divergence among these sympatric populations and, probably, the presence of an incipient species in the Tupi forest park, Piracicaba, which is characterized by native areas planted with eucalyptus.

Furthermore, despite morphological similarity between species, $T$. bruni distinguished from $T$. rojasi and more clearly from $T$. lasallei. Principal component analysis and canonical variate analysis demonstrated the separation between these species, especially between T. bruni and T. lasallei, which are separated by subtle morphological differences. Based on these analyses, the seteae length of the forewing fringe and the length of the posterior extension of the dorsal lamina were found to be important for the differentiation of these species. In addition, the ventral ridge, the position of the ventral processes, the length of the posterior extension of the dorsal lamina and the seteae length of the forewing fringe are diagnostic characteristics of $T$. bruni, T. lasallei and T. rojasi. This species can be easily recognized from $T$. bruni and $T$. lasallei by having the position of the ventral processes and the posterior track of the setae reaching the apex of the hind wing, which are reliable characters for its recognition.

In addition to morphology, crossings confirmed the differences between T. bruni and T. lasallei, demonstrating the complete reproductive isolation between these species. Molecular studies (sequencing of the ITS2 region) conducted on samples of T. bruni, T. lasallei and T. rojasi also confirmed these differences (Ciociola-Júnior, 2001).

The intraspecific variation observed for $T$. bruni is a factor that should be considered for its identification, since the influence of the environment (habitat + host) and the variation among individuals itself is responsible for the plasticity observed in the genital capsule. Therefore, based on the morphological variations of the male genital structures of $T$. bruni, the specimens called "nr. bruni" by Pinto (1998) represent intraspecific variants of $T$. bruni. In the case of pronounced morphological variations, as observed for specimens collected in Brazil from Mechanitis lysimnia, evidence points towards genetic divergence and the presence of an incipient species.

Acknowledgments - We thank FAPESP to the financial support and a fellowship granted to the first author. We also thank Dr. George Washington de Moraes (Universidade Federal de Minas Gerais) who kindly loaned the holotype of Trichogramma bruni and Dr. John D. Pinto (University of California) for some specimens examined in this study. We are grateful to João A. Cerignoni for his assistance in the field.

\section{REFERENCES}

CIOCIOLA Jr., A. I., 2001, Molecular key to seven brazilian species of Trichogramma (Hymenoptera: Trichogrammatidae) using sequences of the ITS2 region and restriction analysis. Neotrop. Entomol., 30(2): 259-262.

NAGARAJA, H., 1983, Descriptions of new Trichogrammatidae (Hymenoptera) from Brasil. Rev. Brasil. Biol., 43: 37-44. 
NAGARKATTI, S. \& NAGARAJA, H., 1971, Redescriptions of some Knowns species of Trichogramma (Hymenoptera: Trichogrammatidae) showing the importance of the male genitalia as a diagnostic character. Bull. Entomol. Res., 61: 13-31.

PINTO, J. D., 1998, Systematics of the north american species of Trichogramma Westwood (Hymenoptera: Trichogrammatidae). Mem. Entomol. Soc. Wash., 22, 287p.

PINTO, J. D., STOUTHAMER, R., PLATNER, G. R. \& OATMAN, E. R., 1991, Variation in reproductive compatibility in Trichogramma and its taxonomic significance (Hymenoptera: Trichogrammatidae). Ann. Entomol. Soc. Am., 84(1): 34-36.

PINTO, J. D., VELTEN, R. K., PLATNER, G. R. \& OATMAN,

E. R., 1989, Phenotypic plasticity and taxonomic character in Trichogramma (Hymenoptera: Trichogrammatidae). Ann. Entomol. Soc. Am., 82: 414-425.
QUERINO, R. B. \& ZUCCHI, R. A., 2000, The use of suction trap to collect Trichogramma species. In: International congress of entomology, 21., Foz do Iguaçu, EMBRAPA SOJA/SEB, p. 410.

SAS Institute, 1990, SAS/STAT user's guide, version $6,4^{\text {th }}$ ed. Cary: SAS Institute Inc.

SOROKINA, A. P., 1993, Key to species of the genus Trichogramma Westw. (Hymenoptera: Trichogrammatidae) of the world fauna. Kolos Publishing House, Moscow, 77p.

ZUCCHI, R. A. \& MONTEIRO, R. C., 1997, O gênero Trichogramma na América do Sul. In: J. R. P. Parra \& R. A. Zucchi (ed.), Trichogramma e o controle biológico aplicado. FEALQ, Piracicaba, 324p. 